\title{
Toxicological impacts of a botanical pesticide, azadirachtin on corpuscles of Stannius of stinging catfish, Heteropneustes fossilis
}

\author{
A. Kumar $\cdot$ M. Prasad $\cdot$ S. K. Srivastav $\cdot$ \\ N. Suzuki • A. K. Srivastav
}

Received: 29 December 2012/Revised: 27 July 2013/Accepted: 2 November 2013/Published online: 27 November 2013

(C) Islamic Azad University (IAU) 2013

\begin{abstract}
Heteropneustes fossilis were subjected to $41.89 \mathrm{mg} \mathrm{L}^{-1}$ of azadirachtin for short-term exposure $(96 \mathrm{~h})$ and $10.47 \mathrm{mg} \mathrm{L}^{-1}$ of azadirachtin for long-term exposure (28 days). The fish were killed on $24,48,72$ and $96 \mathrm{~h}$ in shortterm and 7, 14, 21 and 28 days in long-term experiment. Corpuscles of Stannius (CS) were fixed on these time intervals. CS remain unchanged till $72 \mathrm{~h}$ in short-term azadirachtin exposure. Accumulation of granules has been noticed in the aldehyde fuchsin (AF)-positive cells at $96 \mathrm{~h}$. The nuclear volume of these cells remains unchanged. The AF-negative cells of CS of azadirachtin-exposed fish exhibit a slight increase in their nuclear volume after $96 \mathrm{~h}$. In long-term exposure, the CS remain unchanged up to day 14. Increased granulation in the AF-positive cells has been noticed following 21-day exposure. Moreover, the nuclear volumes of these cells show a significant decrease. Heavy accumulation of AFpositive granules and few degenerating cells are also noticed at 28 day in azadirachtin-exposed $H$. fossilis.
\end{abstract}

Keywords Botanical pesticide - Corpuscles of Stannius · Calcium $\cdot$ Heteropneustes fossilis

\section{Introduction}

Botanical pesticides are the chemicals that have evolved in plants for their defense against phytophagous insects. For

A. Kumar · M. Prasad · S. K. Srivastav · A. K. Srivastav ( () Department of Zoology, D.D.U. Gorakhpur University, Gorakhpur 273009, India

e-mail: ajaiksrivastav@hotmail.com

N. Suzuki

Noto Marine Laboratory, Institute of Nature and Environmental Technology, Kanazawa University, Noto-cho, Ishikawa 927-0553, Japan the control of insect pests, several plants have now been used (Komalamisra et al. 2005; Rahuman et al. 2008; Sileshi et al. 2009; Dubey et al. 2010). The seed, leaves and other parts of neem tree Azadirachta indica (family Meliaceae) contain an insecticidal active ingredient-azadirachtin $\left(\mathrm{C}_{35} \mathrm{H}_{44} \mathrm{O}_{16}\right)$. It is a naturally occurring substance related to an organic molecule class-tetranortriterpenoids (limonoids). Azadirachtin is now used for control of pests and other harmful animals (Punzo and Parker 2005; Mondal et al. 2007; Winkaler et al. 2007; Senthil Nathan et al. 2008; Shanmugasundaram et al. 2008). Inhibition of acetylcholinesterase activity in various fish tissues has been reported by exposure to neem seed pesticide-neemta (Parveen et al. 2004). It has been reported that azadirachtin significantly enhanced the antibody response and an inverse relationship was observed between the dose of azadirachtin and the degree of immunostimulation (Chitra et al. 2008). Azadirachtin is also used in fish farms for the control of fish parasites and fish fry predators (Winkaler et al. 2007).

In fish, toxicants present in aquatic environment disturb water and ion homeostasis. These physiological disturbances have been correlated with the structural damage of the gills caused by these toxicants as gills are supposed to be an important organ for the uptake, biotransformation and excretion of toxicants (Evans 1987; Wendelaar Bonga and Lock 1992; Agbozu et al. 2007). In spite of their great vital importance, gills are delicate structures which are affected by all kinds of environmental influences, such as physical changes of water, microorganisms and toxicants. Any amount of damage to the gills would result in immediate effect on ion homeostasis and will evoke compensatory osmoregulatory responses. Calcium, in vertebrates, plays a vital role in a variety of biological processes such as membrane permeability, muscle contraction, neuronal 
excitability, cell adhesion, fluctuations in acid-base balance and clotting of blood. It is also essential for ultimate initiation of many endocrine events. All vital processes depend on changes in osmotic concentration and ion composition of the body fluids. Any alteration in osmotic and ionic regulation would affect the normal physiological processes of the organisms and hence their survival in nature.

Corpuscles of Stannius (CS) are located on the kidney of holostean and teleostean fishes and considered to be unique to these groups of fishes. CS are superficially attached or partially/deeply embedded in the posterior two-third of kidney, located ventrally or ventrolaterally. They are oval, round or irregular in shape. The CS exhibit variation in number and are asymmetrically located. A thick connective tissue capsule envelops the gland and isolates it from the rest of the kidney tissue. From the capsule, connective tissue septa extend in the gland dividing the CS into several complete or incomplete cords or lobules. These cell cords contain epithelial cells possessing oval or rounded nuclei with sharp staining chromatin granules and often a small central nucleolus.

CS secrete the antihypercalcemic hormone stanniocalcin (STC) (Wendelaar Bonga and Pang 1991; Wagner 1994). Within the CS of few fish species, different cell types have been observed and were considered as type-1 (AF-positive) and type-2 cells (AF-negative) (Wendelaar Bonga and Pang 1991; Singh and Srivastav Ajai 1996; Srivastav Ajai et al. 2009, 2010; Mishra et al. 2009, 2010). The accumulation of secretory granules in the AF-positive cells can be considered as a good measurement for inactivity of these cells, which clearly indicates the inhibited release of granules thereby causing inhibited secretion of stanniocalcin. Presence of functional receptors for STC in nonpiscine vertebrates has been suggested by few investigators on the basis of their experiments in which they observed CS extract-induced hypocalcemia in bird (Srivastav Ajai and Swarup 1982) and snake (Hasan and Das 1987). Ishibashi and Imai (2002) have suggested that STC homologs may also be present in tetrapods. Although no homologous structure of CS has been localized in higher vertebrates, immunocytochemically stanniocalcin (STC 1 and STC 2) has been identified in the kidney, ovary, pancreas (alpha cells) and bladder of human and rat (Ishibashi and Imai 2002; Song et al. 2006; Sazonova et al. 2008; Trindade et al. 2009). Recently, Roch and Sherwood (2010) have cloned three stanniocalcins from two invertebrates, the tunicate Ciona intestinalis and the amphioxus Branchiostoma floridae. Nowadays, STC1 is gaining more and more importance and has been shown to activate antioxidant pathways in endothelial cells and macrophages, thus displaying cytoprotective and anti-inflammatory actions (Sheikh-Hamad 2010).

Although several reports have shown that botanical pesticides can cause biochemical and histological changes in fishes (Chandra and Khuda-Bukhsh 2004, Winkaler et al. 2007) and mammals (Rahman et al. 1999, 2001; James et al. 2009), there is no study regarding their effect on endocrine regulation of calcium homeostasis in fish. The present study is the first report which aimed to access the effects of azadirachtin (trade name-Ozoneem Aza) on histological changes in the CS of stinging catfish, Heteropneustes fossilis.

\section{Materials and methods}

\section{Collection and handling of fish}

Stinging catfish (96 fish; body weight $23-29 \mathrm{~g}$; total body length 14-17 cm) were collected locally (from Ramgarh Lake, Gorakhpur) and acclimatized for 15 days in plastic tanks (dimensions 48 inch $\times 40$ inch $\times 22$ inch; capacity 125 gallon) under laboratory conditions. The physicochemical characteristics of the tap water used in the experiment were temperature $26.74 \pm 2.11 \mathrm{C}$; $\mathrm{pH}$ $7.26 \pm 0.09$; hardness $135.25 \pm 5.69 \mathrm{mg} \mathrm{L}^{-1}$ as $\mathrm{CaCO}_{3}$; dissolved oxygen $7.85 \pm 0.36 \mathrm{mg} \mathrm{L}^{-1}$ and no free chlorine. Water (entire volume) was renewed daily. The fish were fed daily with wheat flour pellets and ground-dried shrimps (prepared in the laboratory), 2-3 times per day (fed to saturation) during acclimatization period. The fish were not fed $24 \mathrm{~h}$ before and during the experimental period. The study was approved by the Animal Research Ethical Committee of DDU Gorakhpur University.

\section{Procurement of extract and dose}

Purified neem extract 'Ozoneem Aza' (containing azadirachtin A $23.78 \%$ and azadirachtin B $3.59 \%$; Batch No. AZA-351, manufactured by Ozone Biotech, India) was used in the present study. The $96 \mathrm{~h} \mathrm{LC}_{50}$ value of azadirachtin for $H$. fossilis is $52.35 \mathrm{mg} \mathrm{L}^{-1}$ (Kumar et al., 2010). The fish were subjected to $41.89 \mathrm{mg} \mathrm{L}^{-1}$ of azadirachtin $\left(0.8\right.$ of $\left.96 \mathrm{~h} \mathrm{LC}_{50}\right)$ for $96 \mathrm{~h}$ in short-term exposure. In long-term exposure, the experiment was performed for 28 days by using $10.47 \mathrm{mg} \mathrm{L}^{-1}$ of azadirachtin $(0.2$ of $96 \mathrm{~h} \mathrm{LC}_{50}$ ). Concurrently, a control group was also run using the tap water containing alcohol due to that azadirachtin was firstly dissolved in alcohol and then added to tap water to obtain the desired concentration. No mortality was noticed during the experimental period.

\section{Histological procedure}

Six fish were killed (anesthetized with MS 222) on each time interval from both control and azadirachtin groups after 24, 48, 72 and $96 \mathrm{~h}$ in short-term exposure and after 7 , 


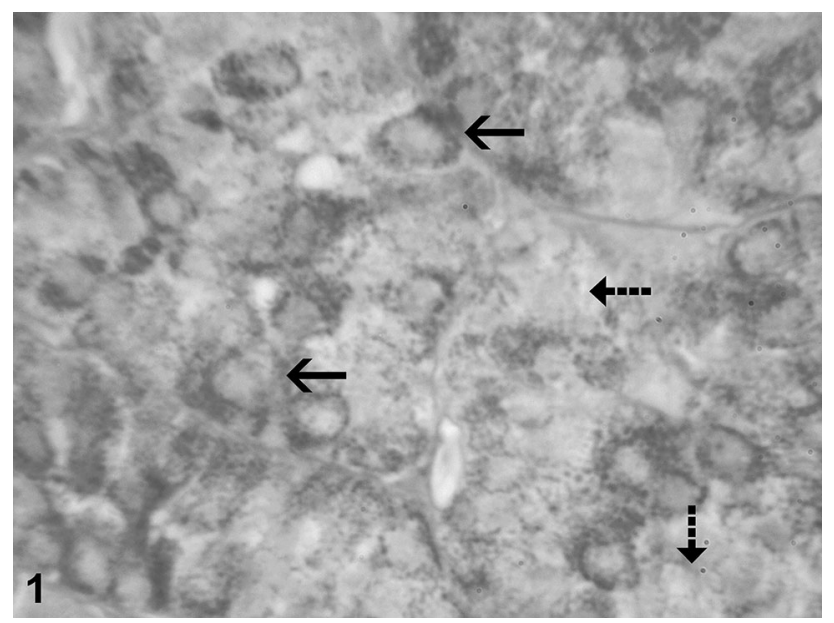

Fig. 1 Corpuscles of Stannius of control fish exhibiting AF-positive (arrows) and AF-negative cells (broken arrows). $\mathrm{AF} \times 500$

14, 21 and 28 days in long-term experiment. The CS were fixed in aqueous Bouin's fluid. These fixed tissues were dehydrated in an ethanol gradient, treated with a clearing agent, infiltrated and embedded in paraffin, sectioned at $6 \mu \mathrm{m}$, floated on a heated water bath and mounted to glass slides. After drying overnight, paraffin was removed with a clearing agent, and tissue was rehydrated in an ethanol gradient and then stained with aldehyde fuchsin (AF) for light microscopic examination (Olympus $\mathrm{CH} 20 \mathrm{i}$ ). Photomicrographs were taken with the aid of Olympus E 420 camera.

\section{Statistical analysis}

The nuclear indices (maximal length and maximal width) of CS were determined (fifty nuclei were measured per specimen, thus 300 nuclei were measured from six specimens) with the aid of an ocular micrometer and then the nuclear volume was calculated as:

volume $=4 / 3 \pi a b^{2}$

where ' $a$ ' is the major semiaxis and ' $b$ ' is the minor semiaxis.

Student's $t$ test was used to analyze the statistical significance between the control and azadirachtin-treated fish. All data are presented as the mean $\pm \mathrm{SE}$ of six specimens. The data were also subjected to two-way analysis of variance (ANOVA) by using treatment and time interval.

\section{Results and discussion}

In control fish, two cell types-AF-positive and AF-negative-have been noticed after AF staining (Fig. 1).

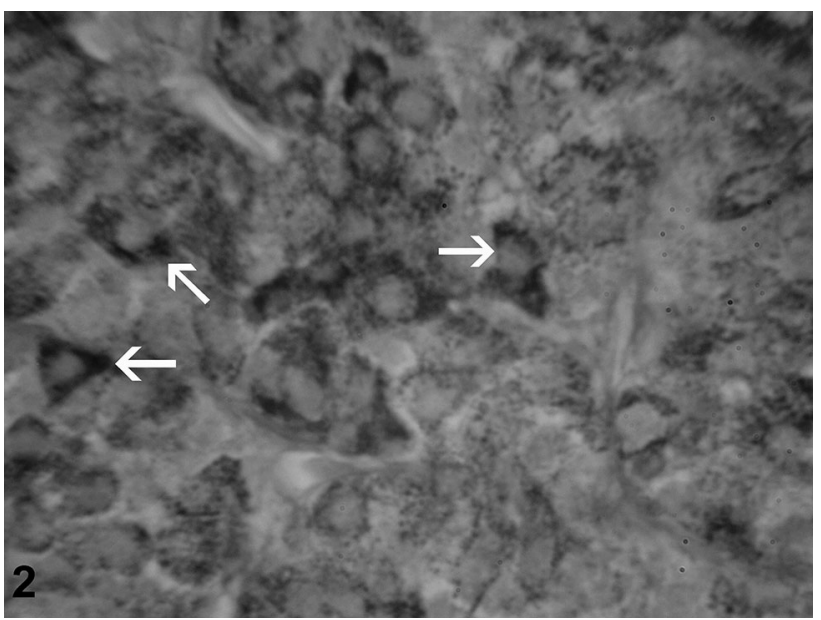

Fig. 2 Corpuscles of Stannius of $96 \mathrm{~h}$ azadirachtin-treated fish showing increased granulation (arrows) in AF-positive cells. AF $\times$ 500

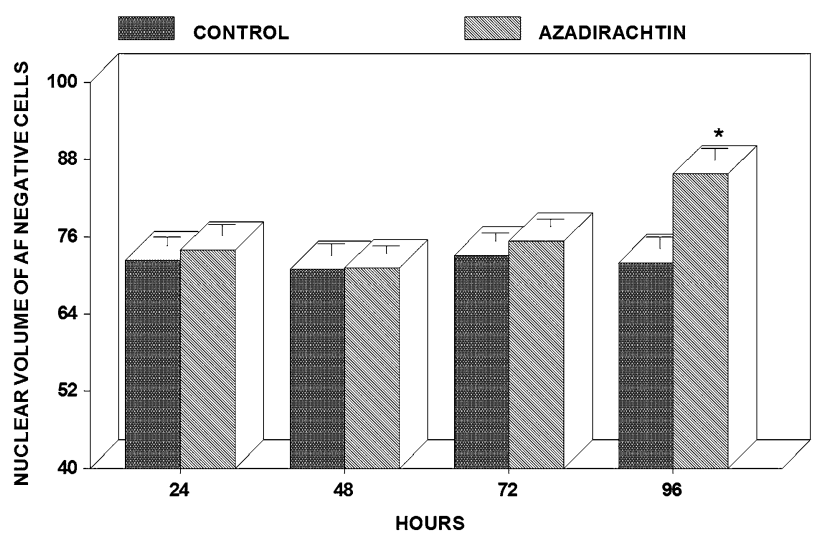

Fig. 3 Nuclear volume of AF-negative cells of $H$. fossilis treated with azadirachtin for short term. Each value represents mean \pm S.E. of six specimens. Asterisk indicates significant differences $(P<0.05)$ from control

Corpuscles of Stannius remain unchanged till $72 \mathrm{~h}$ following short-term azadirachtin exposure. Increased granulation has been noticed in the AF-positive cells at $96 \mathrm{~h}$ (Fig. 2). The nuclear volume of these cells remains unchanged. The AF-negative cells of CS of azadirachtinexposed fish exhibit a slight increase in their nuclear volume after 96 h (Fig. 3).

Analysis of variance indicated that in short-term experiment, the nuclear volume of AF-positive cells was not significant (among time intervals $F=0.22$, ns; between treatments $F=0.98, \mathrm{~ns}$ ), whereas for AF-negative cells, the values were significant (among time intervals, $F=8.96$, $P<0.0001$; between treatments $F=16.24, P<0.0001$ ).

Corpuscles of Stannius remain unchanged up to day 14 in long-term azadirachtin-exposed fish. Increased granulation in the AF-positive cells has been noticed following 


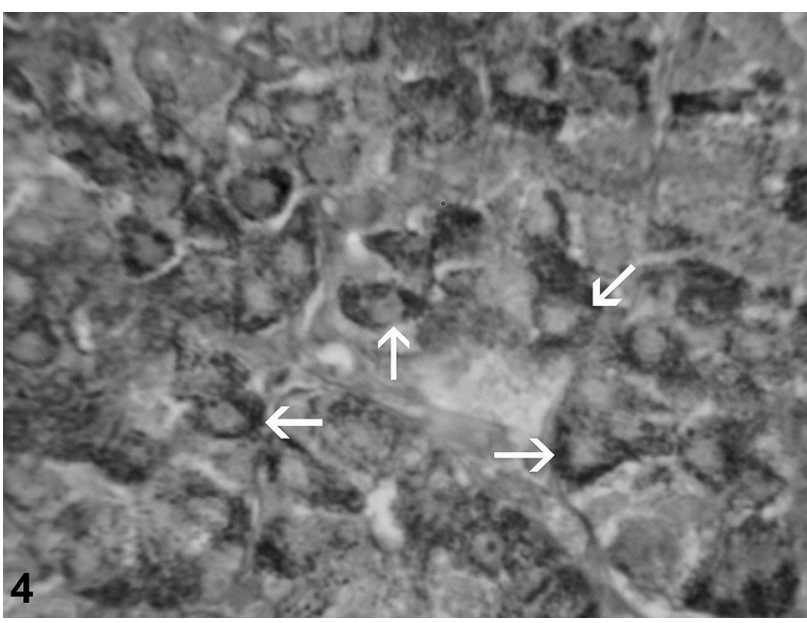

Fig. 4 Increased granulation (arrows) in the AF-positive cells of 21-day azadirachtin-exposed H. fossilis. AF $\times 500$

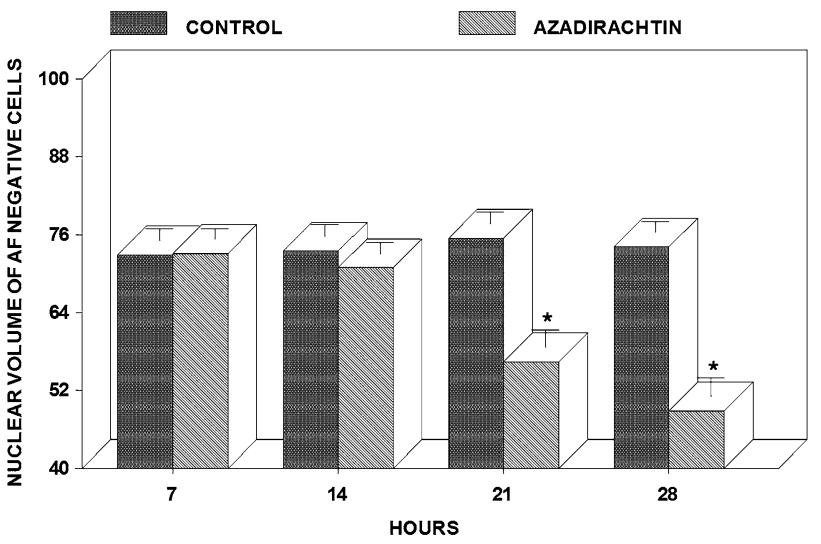

Fig. 5 Nuclear volume of AF-positive cells of long-term azadirachtin-exposed $H$. fossilis. Each value represents mean \pm S.E. of six specimens. Asterisk indicates significant differences $(P<0.05)$ from control

21-day exposure with azadirachtin (Fig. 4). Moreover, the nuclear volume of these cells shows a significant decrease (Fig. 5). Heavy accumulation of AF-positive granules and few degenerating cells (Fig. 6) are also noticed at 28 day in azadirachtin-exposed fish. AF-negative cells of CS remain unchanged till 21 days of azadirachtin exposure. These cells show increase in their nuclear volume after 28 days following the treatment (Fig. 7).

For long-term experiment, ANOVA indicated that the nuclear volume of AF-positive (among time intervals, $F=14.16, P<0.0001$; between treatment, $F=64.59$, $P<0.0001$ ) and AF-negative (among time intervals, $F=17.64, P<0.0001$; between treatment, $F=25.00$, $P<0.0001)$ cells was significantly different.

AF-positive cells of CS of fish responded to azadirachtin treatment by showing an increased accumulation of secretory granules and a decrease in nuclear volume. Prior

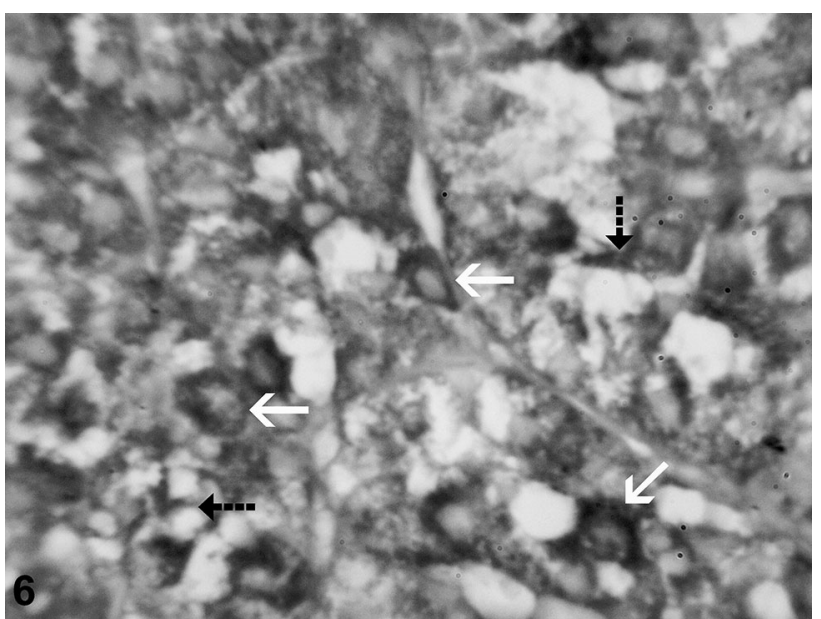

Fig. 6 Corpuscles of Stannius of 28-day azadirachtin-exposed fish showing heavy accumulation of secretory granules (arrows) in AFpositive cells. Also note degenerating AF-positive cells (broken arrow). $\mathrm{AF} \times 500$

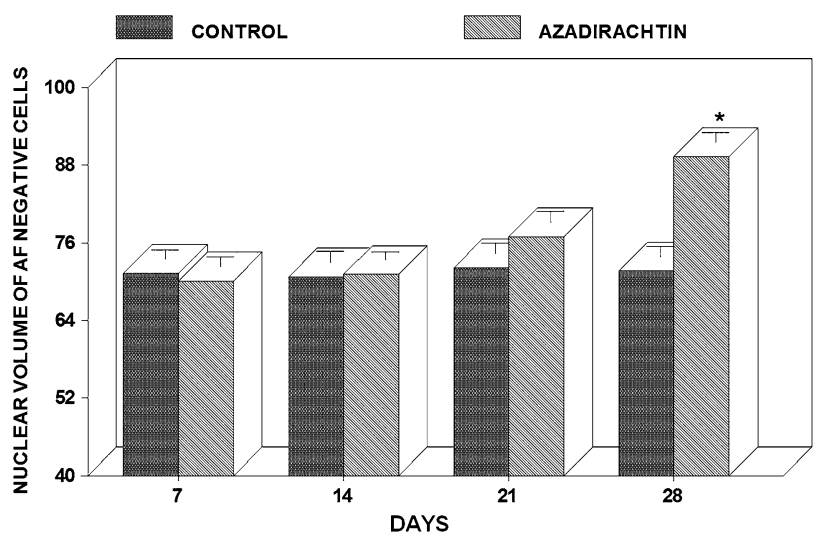

Fig. 7 Nuclear volume of AF-negative cells of long-term azadirachtin-exposed $H$. fossilis. Each value represents mean \pm S.E. of six specimens. Asterisk indicates significant differences $(P<0.05)$ from control

to this study, responses of CS have not been studied after exposure to botanical pesticide. Accumulation of secretory granules and decreased nuclear volume of AF-positive cells have been recorded earlier by few investigators in response to exposure of fish to various toxicants (Srivastav Ajai et al. 2009, 2010; Mishra et al. 2009, 2010). AFpositive cells (type-1 cells) of the CS have been implicated with branchial calcium uptake in the fish through the secretion of a hypocalcemic hormone-stanniocalcin (Wendelaar Bonga and Pang 1991; Srivastav Ajai and Srivastav 1988; Tseng et al. 2009). The increased granulation in the AF-positive cells after azadirachtin exposure may be due to the prolonged hypocalcemia reported by Kumar et al. (2011) by similar treatment and can be explained on account of inhibition of the hormonal release and continued biosynthesis of STC. Accumulation of AF- 
positive granules in CS has been noticed earlier in response to experimentally induced hypocalcemia in fishes kept in ambient acalcic freshwater (Tiwari 1993; Singh and Srivastav Ajai 1996). Similar accumulation of secretory granules in the calcitonin cells (responsible for the secretion of a hypocalcemic factor-CT) of mammals has also been noticed in response to hypocalcemia (Biddulph and Maibenco 1972; Swarup et al. 1980).

\section{Conclusion}

From the results of the present study, it is concluded that exposure of the fish to azadirachtin provoke disturbances in the blood calcium levels as well as in the histological structure of CS. As calcium is important for many vital functions including reproduction in the fish, any change in the blood calcium content would pose threat to these biological processes. Hence, near the fish ponds, azadirachtin should be used more carefully.

Acknowledgments Authors are highly thankful to Ozone Biotech, India, for providing "Ozoneem Aza".

\section{References}

Agbozu IE, Ekweozor IKE, Opuene K (2007) Survey of heavy metals in the catfish Synodontis clarias. Int $\mathbf{J}$ Environ Sci Tech 4(1):93-97

Biddulph DM, Maibenco HC (1972) Response of hamster thyroid light cells to plasma calcium. Anat Rec 173:25-43

Chandra P, Khuda-Bukhsh AR (2004) Genotoxic effects of cadmium chloride and azadirachtin treated singly and in combination in fish. Ecotoxicol Environ Safe 58:194-201

Chitra G, Thamizharasi A, Krishnaveni N (2008) Neem (Azadirachta indica) extract as an immunostimulant in freshwater fish Catla catla. Ecology Environ Cons 14:559-560

Dubey NK, Shukla R, Kumar A, Singh P, Prakash B (2010) Prospects of botanical pesticides in sustainable agriculture. Curr Sci 98:479-480

Evans DH (1987) The fish gill: site of action and model for toxic effects of environmental pollutants. Environ Health Persp 71:47-58

Hasan N, Das S, Srivastav Ajai K, Swarup K (1987) Phosphocalcic response of Stannius corpuscles extract in the freshwater snake, Natrix piscator. Zool Sci 4:391-394

Ishibashi K, Imai M (2002) Prospect of a stanniocalcin endocrine/ paracrine system in mammals. Am J Physiol Renal Physiol 282:F367-F375

James DB, Ameh DA, Agbaji AS, Ibrahim NDG (2009) Biochemical and histologic effect of dietary substitution with solvent extracted neem seed cake of Albino rats (wistar strain). Int $\mathbf{J}$ Anim Vet Adv 1:1-5

Komalamisra N, Trongtokit Y, Rongsriyam Y, Apiwathnasorn C (2005) Screening for larvicidal activity in some thai plants against four mosquito vector species. Southeast Asian J Trop Med Pub Health 361:412-422

Kumar A, Prasad M, Mishra D, Srivastav SK, Srivastav Ajai K (2010) Acute Toxicity of Azadirachtin to a Teleost, Heteropneustes fossilis. Acta Sci Biol Sci 34:213-216
Kumar A, Prasad M, Mishra D, Srivastav SK (2011) Srivastav Ajai K. Botanical pesticide, azadirachtin attenuates blood electrolytes of a freshwater fish Heteropneustes fossilis. Pest Biochem Physiol 99:170-173

Mishra D, Srivastav SK, Suzuki N, Srivastav Ajai K (2009) Corpuscles of Stannius of a freshwater teleost, Heteropneustes fossilis in response to metacid-50 treatment. J app Sci Manag 13:69-77

Mishra D, Tripathi S, Srivastav SK, Suzuki N (2010) Srivastav Ajai $\mathrm{K}$. Corpuscles of Stannius of a teleost, Heteropneustes fossilis following intoxication with a pyrethroid (cypermethrin). NorthWest. J Zool 6:203-208

Mondal D, Barat S, Mukhopadhyay MK (2007) Toxicity of neem pesticides on a fresh water loach, Lepidocephalichthys guntea (Hamilton Buchanan) of Darjeeling district in West Bengal. J Environ Biol 28:119-122

Parveen M, Sharma R, Kumar S (2004) Effect of neem seed pesticide, neemta-2100 to the Tilapia mossambica. Asian J Microbio Biotech Environ Sci 6:567-569

Punzo F, Parker M (2005) Effects of azadirachtin on mortality, fertilization, and swimming speed in larvae of the cane toad, Bufo marinus (Anura: Bufonidae). J Environ Biol 26:687-691

Rahman MF, Siddiqui MKJ, Jamil K (1999) Sub-chronic effect of neem based pesticide (vepacide) on acetylcholinesterage and ATPases in rat. J Environ Sci Health B 34:873-884

Rahman MF, Siddiqui MKJ, Jamil K (2001) Effect of Vepacide (Azadirachta indica) on aspartate and alanine aminotransferase profiles in a sub-chronic study with rats. Human Exp Toxicol 20:243-249

Rahuman AA, Gopalakrishnan VGP, Geetha K (2008) Larvicidal activity of some Euphorbiaceae plant extracts against Aedes aegypti and Culex quinquefasciatus (Diptera: Culicidae). Parasitol Res 102:867-873

Roch GJ, Sherwood NM (2010) Genomics reveal ancient forms of stanniocalcin in amphioxus and tunicate. Int Comp Biol 50:86-97

Sazonova O, James KA, McCudden CR, Segal D, Talebian A, Wagner GF (2008) Stanniocalcin-1 secretion and receptor regulation in kidney cells. Am J Physiol Renal Physiol 294:F788-F794

Senthil Nathan S, Young Choi M, Yul Seo H, Hoon Paik C, Kalaivani K, Duk Kim J (2008) Effect of azadirachtin on acetylcholinesterase (AChE) activity and histology of the brown planthopper Nilaparvata lugens (Stal). Ecotoxicol Environ Safe 70:244-250

Shanmugasundaram R, Jeyalakshmi T, Sunil Dutt M, Balakrishna Murthy P (2008) Larvicidal activity of neem and karanja oil cakes against mosquito vectors, Culex quinquefasciatus (Say), Aedes aegypti (L.) and Anopheles stephensi (L.). J Environ Biol 29:43-45

Sheikh-Hamad D (2010) Mammalian stanniocalcin-1 activates mitochondrial antioxidant pathways: new paradigms for regulation of macrophages and endothelium. Am J Physiol Renal Physiol 298:F248-F254

Sileshi GW, Nyeko P, Nkunika POY, Sekematte BM, Akinnifesi FK, Ajayi OC (2009) Integrating Ethno-ecological and scientific knowledge of termites for sustainable termite management and human welfare in Africa. Ecol Soc 14:48. www. ecologyandsociety.org/vol14/iss1/art48/

Singh S, Srivastav Ajai K (1996) Vitamin D3 induced histological changes in the corpuscles of Stannius of a freshwater catfish, Heteropneustes fossilis kept either in artificial freshwater, calcium-rich freshwater or calcium deficient freshwater. Okajimas Fol Anat Jap 73:75-82

Song G, Bazer FW, Wagner GF, Spencer TE (2006) Stanniocalcin (STC) in the endometrial glands of the ovine uterus: regulation by progesterone and placental hormones. Biol Reprod 74:913-922 
Srivastav Ajai K, Srivastav SP (1988) Corpuscles of Stannius of Clarias batrachus in response to 1,25 dihydroxyvitamin $\mathrm{D}_{3}$ administration. Zool Sci 5:197-200

Srivastav Ajai K, Swarup K (1982) Calcemic responses of Stannius corpuscles extract in parrots, Psittacula psittacula. Experientia $38: 869$

Srivastav Ajai K, Srivastava SK, Mishra D, Srivastav SK, Suzuki N (2009) Effects of deltamethrin on serum calcium and corpuscles of Stannius of freshwater catfish, Heteropneustes fossilis. Toxicol Environ Chem 91:761-772

Srivastav Ajai K, Srivastava SK, Tripathi S, Mishra D, Srivastav SK (2010) Chlorpyrifos based commercial formulation: alterations in corpuscles of Stannius of catfish. Int $\mathrm{J}$ Environ Health 4:323-332

Swarup K, Tewari NP, Srivastav Ajai K (1980) Response of calcitonin cells, parathyroid glands and bone to prolonged calcitonin administration in the Indian palm squirrel Funambulus pennanti (Wroughton). Acta Anat 106:180-191

Tiwari PR (1993) Endocrinal regulation of calcium in teleost. Ph.D. Thesis University of Gorakhpur, Gorakhpur India
Trindade DM, Silva JC, Navarro MS, Torriani ICL, Kobarg J (2009) Low resolution structural studies of human Stanniocalcin-1. BMC Struct Biol 9:57

Tseng DY, Chou MY, Tseng YC, Hsiao CD, Huang CJ, Kaneko T, Hwang PP (2009) Effects of Stanniocalcin 1 on calcium uptake in zebrafish (Denio rerio) embryo. Am J Physiol Reg Inte Comp Physiol 296:R549-R557

Wagner GF (1994) The molecular biology of the corpuscles of Stannius and regulation of Stanniocalcin gene expression. In: Sherwood NM, Hew CL (eds) Fish physiology, vol VIII. Academic Press, San Diego, pp 273-306

Wendelaar Bonga SE, Lock RAC (1992) Toxicants and osmoregulation in fish. Netherlands J Zool 42:478-493

Wendelaar Bonga SE, Pang PKT (1991) Control of calcium regulating hormones in the vertebrates: parathyroid hormone, calcitonin, prolactin and stanniocalcin. Int Rev Cytol 128:139-213

Winkaler EU, Santos TR, Machado-Neto JG, Martinez CB (2007) Acute lethal and sublethal effects of neem leaf extract on the neotropical freshwater fish Prochilodus lineatus. Comp Biochem Physiol C Toxicol Pharmacol 145:236-244 